\title{
Ideology and Emancipation in Maria Susanna Cummins
}

\author{
Goetz Egloff ${ }^{1,2}$ \\ ${ }^{1}$ Coeditor, Yearbook of Psychohistorical Research, Heidelberg, Germany \\ ${ }^{2}$ Practice for Psychoanalysis, Mannheim, Affil, University of Heidelberg, Heidelberg, Germany
}

\section{Email address:}

goetz.egloff@alumni.uni-heidelberg.de, g.egloff.medpsych.ma@email.de

\section{To cite this article:}

Goetz Egloff. Ideology and Emancipation in Maria Susanna Cummins. International Journal of Literature and Arts. Vol. 3, No. 6, 2015, pp. 166-170. doi: 10.11648/j.ijla.20150306.17

\begin{abstract}
The essay highlights aspects of ideology and of emancipation issues in Maria Susanna Cummins' novel, The Lamplighter, published in 1854. Being a domestic, or sentimental, novel it reached a wide range of readers, as did many of contemporary female authors referred to as literary domestics. Though simply structured, The Lamplighter carries a specific view as to life at home and life in the world, relating to central issues of female readers' self-perception and self-concept. Benevolence and enlightenment as central ideas of socialization give insight into the ways and the goals of the early republic. In the novel, aspects of affirmation take turns with aspects of autonomy in the image of how women were supposed to be like. Obvious differences in background, class, and behavior hint at the morals and manners of a society on the cusp of becoming the nation-to-be. Cummins is shown to promote what is a moderate approach of achieving a middle position between poverty and fashion. Mostly didactic in her presentation of the protagonists, Cummins advocates a kind of Protestantism that is grounded in the concept of man being generally capable and in need of undergoing a gradual educative process. With that the author rejects the Calvinism then still strong in New England, and she advocates for candor in antebellum contemporaries.
\end{abstract}

Keywords: Maria Susanna Cummins, The Lamplighter, Domestic Novel, Sentimental Novel, Literary Domestics

\section{On the Concept of the Domestic Novel}

"The many novels all tell, with variations, a single tale." [1] The female authors that are referred to as literary domestics, [2] e.g. Maria McIntosh, Catharine Sedgwick, E.D.E.N. Southworth, and Maria Susanna Cummins, amongst others, all told a single tale. This tale, in today's perspective referred to as the domestic novel, was by and large a trials and triumph story. Definingly different from the writings of their male contemporaries, the literary domestics chose to have their main protagonists be females as well as having a female perspective at the core center of their concern. A young girl, being on her way to maturity and having to pave her way through individuation defying all obstacles is common in most of those novels. "In Jungian perspective, her story exemplifies the difficult but successful negotiation of the undifferentiated child through the trials of adolescence into the individuation of sound adulthood." [3] Thus the novels of the literary domestics respond to the concept of the bildungsroman, depicting the initiation and the education of their protagonists. In Cummins' novel, The Lamplighter (1854), orphan Gerty develops from an uncivilized, not yet socialized kid - i.e. in Cummins' view: a social misfit who is socially and religiously unfit for bonding - into a civilized, educated, and virtuous member of community and of society. This can be highlighted through three passages in the text. In the beginning it says, "No one loved her, and she loved no one (...). She was all alone in the world." [4] A little later on, it says, "(...) a new direction must be given to her ideas, new nourishment to her mind, new light to her soul (...)," [5] pointing at the very direction in which the protagonist is to develop. At the end, after her transformation has been carried out, she even reflects on herself: “'(...) you must cultivate your heart.'" [6]

Depicting the process of enlightenment was the basic idea of the literary domestics. Taking a chance at inform readers of their ideas of morals, their writings aimed at a guidebook function. Yet, any educational effect would only be possible through high circulation of their writings; indeed the authors by and by experienced reception by a mass readership. Readers would almost entirely be women, a fact commending itself to the authors to write fiction from women and for women. "By the nineteenth century, a book became a symbol of status, especially among fashionable young women (...)." [7] Nevertheless, the surroundings in their male and female aspects of effect on the protagonists were depicted; even when in The Lamplighter females are at the center of the main plot 
and the sub plots. Isolating of gender specific characteristics was not in focus, instead the mediation of values and of morals was the issue of the authors: how to achieve it and how to not lose it in spite of worldly obstructions. An emancipate approach can be seen in the authors' own specifically female view of the world, supposedly inducing self-reflection in their mostly female readers. The protagonists in their experiencing of clarity of vision would pave the way toward epiphanies in the readers, thus making one little step in the direction of better lives: "The women (i.e. the authors) expressed a wish to live somewhat less brutal lives than their sex had in the past." [8] The question is how authors like Cummins viewed the role of women at the time and how they assessed and depicted the possibility of first steps toward emancipation. By putting the home space at the center of the plot, the literary domestics especially contrasted "world" with "home" as anti-poles. [9] The protagonists' places were destined to be in home surroundings, acting in their limits, and crossing none of them. Home surroundings were thus depicted as good and somewhat blessed places, encompassing the conditions of achieving enlightenment to full extent. At the same time, the outside world would implicitly be excluded from both potential spaces since only home as a place of "sympathy, honor, virtue" [10] was seen as capable of practicing of benevolence, thus making domesticity the central leitmotif.

\section{On Ideology in Cummins' The Lamplighter}

"Poor little, untaught, benighted soul! Who shall enlighten thee? Thou art God's child, little one! Christ died for thee." [11] The narrator's commentary, uttered in the very first chapter as to orphan Gerty's situation, is an essential expression in The Lamplighter, giving insight into Cummins' concept of an anthropological need of developmental motion that has to be made in order to achieve being human. Little Gerty, at that point of time still raw, uncivilized, almost animal-like, in terms of morals is in a vacuum. An enlightenment process will have to take place. The odds are open as to her socialization; maybe she will get lost, get defeated by the dark and sinister influence of her mother ersatz Nan Grant. Cummins calls for Gerty's enlightenment, at the same time non-calvinistically attributing her with the necessary sensitivity to experience a socialization and enlightenment process. The squalid kid has to undergo enlightenment to make it from an uneducated creature toward a socialized human being. Cummins depicts her sensitivity as a prerequisite for such a process through an interior monolog of Gerty who, while looking in awe at the shining of stars in heaven, asks, "'Who lit it? Somebody lit it! Some good person, I know! (...)'” [12]

After Gerty has been taken in by Trueman Flint her development in the home space is depicted. Beginning with a scene of Mrs. Sullivan giving her the opportunity of helping in clearing up Trueman's room, Gerty feels beneficial for the first time; the main statement seems to be that a home will only be a home with things at the right place. Without external order there will be no internal order, Cummins suggests. A tidy house, a tidy mind. Yet, just as without internal order human relations will not work; "(..) in this view "home" is not a space but a system of human relations; (...)." [13] Cummins here has her protagonist experience utmost feelings of happiness: “(...) that happiness - perhaps the highest earth affords - of feeling that she had been instrumental in giving joy to another." [14] To have recipients not jump the gun in anticipating external and internal disarray in low class only, Cummins puts Nan Grant in opposition to the widow Holbrook: Gerty's low class mother ersatz is in no way inferior to upper class Holbrook who is not only well-off and pleasure seeking but in her escapism is entirely unable to keep any internal order. In that respect, Baym views Cummins to favor a moderate approach of achieving the middle of poverty and fashion: "Among the poor, women are too often overloaded with care; among the rich, they are too often diverted by social entertainments. What we are seeing here, in brief, is the campaign for the stable middle-class style of life as antidote to social turmoil in nineteenth-century America." [15] Apart from a divergence in Cummins' concern of depicting middle class and her actually depicting rather upper class lifestyle like in traveling, Saratoga etc., [16] another insight into her main stance is given here: being born in upper class surroundings does not necessarily have to be a perfect starting point for an individual's development; “(...) those born in honor, wealth and luxury, seldom achieve greatness." [17] Then again, she states a reminiscence of the American Dream and the pursuit of happiness not least by achieving material wealth in a dialog between Gerty and Willie Sullivan: "'O, I shall work, and grow rich, and buy it.' 'You can't; it would take a lot o' money.' 'I know it; but I can earn a lot, and I mean to. (...)" [18] The question, of course, is whether the pursuit of becoming upper class, in contrast to being middle class, is in opposition to Cummins' supposed necessity of enlightenment; in her view, practicing of benevolence seems to be possible through external and internal order in middle class only. One can argue that the process of enlightenment itself will induce self-reflection in the individual, leading to the recognition that the pursuit of material goods only will be rather inimical to practicing of benevolence. The young age of both the protagonists in the dialog may support this perspective. So a minimum of social status seems to be required in order to recognize the necessity of achieving benevolence as top priority. In face of the sprouting of capitalism at that time this would serve the thesis of retreating into the sanctuary of home as an anti-pole of world. Still, from the perspective of the literary domestics, this would be the only opportunity to achieve virtue.

A similar, and seemingly anti-aristocrat, approach is shown in a dialog between Mr. Amory and Willie after he came back from his journey: “(...) I have seen more ignorance, more ill-breeding, more meanness, and more immorality, in the so-called aristocracy of our country, than I should have believed it possible would be tolerated there. I have frequently known instances in which the most accomplished gentleman, 
or the most beautiful lady, of a gay circle, has given evidence of unpardonable want of information on the most common topics." [19]

The main plot, dealing with Gerty's development, in the process offers a quasi-dénouement in the shape of Gerty's rule for politeness: "You must cultivate your heart Miss Bruce; you must cultivate your heart." [20] The fairy tale-like solution of the sub plots, the meeting of her father, her marriage, certainly serve as a reward for Emily's and Gerty's having practiced benevolence; at the same time it turns out to be recognizable that middle class living serves as moral precondition of ascending into the upper class. Gerty has now become able to transfer her philosophy of life to others, therefore she occasionally teaches at schools. Here Cummins presents a slight emancipate approach: autonomy and independence in Gerty as a teacher, even if this is only short-lived and will not go much beyond the domestic sphere. Yet, Saulsbury sees in Cummins' fiction a distinct motion toward expanding the female realm beyond the borders of the domestic sphere. [21]

After Gerty - now Gertrude as an outer sign of her inner maturity - had been wrenched from Nan Grant, and had initially been socialized by the Grahams, she has experienced enlightenment and has practiced benevolence, so she is entitled to transfer her main belief which goes by her rule for politeness. This seemingly minimal formula of social dealings, again, represents Cummins' non-calvinistic stance. In assuming that man is conditioned by environment only she depicts Gerty in her being found by the lamplighter Trueman Flint - whose name stands for enlightenment in the literal as well as in the figurative meaning of the word - as a human being that can and has to be socially shaped. Only by being taken care of by the social community a human being can become part of it at all. Cummins clearly aims at protestant values: "Aimed at an audience of Protestant Christians, The Lamplighter does not argue for Christianity per se but for a particular kind of Protestantism. Holding that the possibility of enlightenment exists in everyone even an abused and abandoned child, it rejects the Calvinism still strong in New England; declaring that enlightenment is a gradual educative process, it rejects the Evangelicalism increasingly prominent in American religious life. Everyone has an inner light, but all need confirmation and strengthening through social relations." [22]

By way of blind Emily benevolently taking in uncivilized Gerty, Cummins presents a generally valid behavioral code of conduct of the relations of humans to God, and with that the relations of humans to one another. In Cummins' view, Emily Graham, in her blindness, represents religion; she is closer to God than any other of the protagonists since she will not let herself be deceived by external, i.e. visual, influence and is in opposition to upper class ethics. By that, the doctrine of divine election is allegorically rejected: Nan Grant represents darkness, Trueman Flint represents light (both of them belong to low class, though); little Gerty represents human life that has not experienced enlightenment yet, were it not for blind Emily (belonging to, in Cummins' depiction, the righteous middle class) practicing benevolence in a fair-minded, nonjudgmental way, and by that enlightening Gerty.

\section{On Emancipation in Cummins' The Lamplighter}

The issue of an emancipate approach in the literary domestics is to be examined within the context of the nineteenth century. From a late twentieth-century or a twenty-first century feminist perspective, the vision of the literary domestics as to taking a bearing on females and on society in the nineteenth century might not seem progressive enough. It is significant that the belief in economic progress was the backdrop that these women authors were writing in. "Many nineteenth-century Americans in the Northeast acted every day as if they believed that economic expansion, urbanization, and industrialization represented the greatest good." [23] In this cultural background of the pursuit of economic wealth the flourishing of the domestic novel can be understood expressive of a down-home stance as an opposite pole of industrialization and alienation. Supposed the anticipated alienation in a growing industrial society called for an artistic counter-world, the domestic novel would exactly have made for it. Domesticity as central motif of that counter-world would address the female public's definition of self-concept. Congruously, the authors would have to merge their didactic concern with entertainment set parts that could be appreciated by the group of readers aimed at; Baym views this as successful: "Instruction is not at cross-purposes with entertainment in this fiction, nor is entertainment the sweet coating on a didactic pill. The lesson itself is an entertainment in that the heroine's triumph over so much adversity and so many obstacles is profoundly pleasurable to those readers who identify with her." [24] Then again, some fifty years later, Kate Chopin would turn triumph into doom, hinting at the limitations of female development [25] in the context of inwardness or escalation, vitality or surrender. [26]

At the same time, the question can be asked what the vision of a better world would actually look like. Is a rejection of the worldly space - that might be derived from the authors' focusing on the home space - actually expressed? Be that not the case, silent acceptance might be at work. Given that the country was on the cusp of developing into an industrial capitalist system, were the literary domestics advocating, endorsing or rejecting it? At first sight, it is not obvious in their texts. In depicting the home space, one might as well recognize indirect support of the worldly space instead of its rejection; even the depiction of the home space as a counter-world does not necessarily induce reflection in readers of it being a counter-world. Certainly, readers were supposed to thoughtfully transfer what they read to their own lives; yet the authors' fictional world would consist of the home space only as there seems to be no aiming at readers' abstractions on the worldly space whatsoever. As to the intention of aiming at the realization of retreat from worldly, 
even hostile life, contemporary female readers, after having read The Lamplighter, might not have felt any impulse of going out to India and get into business, like Willie Sullivan does in the novel. It rather seems it is aimed at an inner reflection in readers as to the values that both spaces, home space and worldly space, are to hold: "If worldly values could dominate the home, perhaps the direction of influence could be reversed so that home values dominated the world." [27]

How might contemporary male readers have read the novel? [28] Having an elaborated plot, it still carries quite a simple message; in a reception aesthetics perspective it might have been perceived as affirmative by male readers. In that case, not much of an emancipate impact would have been left. Yet, Gerty's and Emily's strength will have had a disturbing impact on male readers; so Gerty's independence making a living as a teacher will have been an exception from the role model rule women were subjected to at the time. Gerty's feeling of owing the Sullivans one, her - careful firmness in leaving the Grahams to take care of the Sullivans shows her instantly disregarding patriarchal rules in order to do what in her view morally is the right thing. [29] So there definitely is an emancipate approach present, even if the overall female image that is drawn serves devotion to be the foremost capability of being female. Supposed that Cummins views devotion as utmost virtue, the advocating of the abandonment of one's own will should be close at hand. Kelley sums up the approach, "The most compelling testimony to woman's superiority is her boundless capacity for devotion to others." [30] Some one-hundred years later, Betty Friedan would emphatically put this at question. [31] But not just the abandoning of her own will makes Gerty a valuable member of society - or is it rather, a lovable member of society, as Harris suggests? [32] Above all, she is supposed to not show any emotions, not show any temper. At the beginning of her development she does; [33] she even throws a stone at Nan's window, [34] followed by the very chapters of her educational process, that is, in terms of emotions, a process of abandoning of showing any temper. She has to undergo recognizing total self-control to be the basic condition of becoming a civilized, virtuous human being. "Temper, the unrestrained expression of passion and anger, is the novel's word for all that is most destructive in human relations. It also stands for that which destroys the self." [35] Thus, it is not the expression of human emotions that is aimed at but it is exactly the opposite, the suppression of emotions - this, of course, from a Freudian perspective being a rather questionable approach. Then again, the mere utterance of emotions is what is not welcomed, not the emotions themselves; in the course of cultural development certainly a necessary precondition for living together. Sublimation in the sense of, "Wo Es war, soll Ich werden" (Where id was, there ego shall be), [36] in American ego-psychology would become the basic concept of personal and societal raison d'être for a long time. Moreover, in the conflict between Gerty and Mr. Graham, not emotion but duty is dealt with; the issue at stake is whether Gerty's sense of duty preponderates as to the Grahams or to the Sullivans.
"Neither love nor pleasure are at issue here; it is a matter of principle (...)", [37] just as the road toward enlightenment seems to be paved with principles. Baym hints at the socio-cultural context of the western way of life as a background of strategically well-considered restraint; [38] social accommodation rather than realization of one's own goals would be the name of the game.

Along with an approach of careful emancipate thought, the concept of virtuous behavior leading to material success [39] is obvious in the domestic novel. This being a distorted vision, yet having affirmative impact on readers, to some extent it denies the existing issues of human beings, and offers somewhat restricted options of behaving. Probably, Davidson is right in summing up that, "The sentimental novel, in particular, was generically suited to addressing, in detail, the range of ideological assessments of the family and the implications for women of different visions of what the family should be." [40]

\section{Conclusion}

The success that The Lamplighter was and that led Nathaniel Hawthorne to complain about in 1855 [41] accounts for the sentimental tradition of British ancestry that Susanna Rowson in 1791 and Hannah Webster Foster in 1797 had reinvented in the US at first. [42] It elevates the tradition onto a level of impetus of societal changes to come, though. The changes in woman image and self-concept would be continued by diverse women authors and topics, and on different artistic levels, of which certainly Kate Chopin would create one of the most fully-fledged novels at that time, [43] anticipating modernist issues of conflict of self-realization and societal demand. Looking at woman image and self-concept generally, hallmarks of excellence would follow with modernism and high modernism, and with varying emphases, realized by authors such as D.H. Lawrence drawing a woman of desire, and pointing to concepts of Krafft-Ebing, Freud, and Gross. [44] A counterpoint woman character depiction might be seen in Lucy Nelson in Philip Roth [45], surrounded and followed by a variety of women issues at that time, up to the point where whole forms would change, be parodied, and be wholly put at question. [46]

As Kerber states, the History of America could not have been written without focusing on women's lives in the period. They are the essentials of an understanding of the early republic. [47] Not only Harriet Beecher Stowe is to be set against the backdrop of societal changes at the time but also the literary domestics in their effects on women's lives. Their writings and doings point to their strong participation in history writing. [48] The intentions of the literary domestics may look simple, their motifs easily accountable. Yet, there is a potential in their writings which is clearly political. Baym puts it, "Woman, if she can preside over the home space, will then be not out of the world but at the very center of it. When accepting, as one's basic relation to another, obligation rather than exploitation, doing another good rather than doing him in; when books and conversation and simple comfort seem 
superior to ostentation and feverish pleasure - then, our authors believed, a true social revolution will have taken place, American life will have been transformed." [49] This exactly would be the main concern of the literary domestics; a new vision of a political framework that derives its existence from private life, transforming it into political life.

\section{References}

[1] Baym N (1978). Woman's Fiction: A Guide to Novels by and about Women in America, 1820 - 1870. Ithaca: Cornell University Press, p. 11.

[2] Term from: Kelley M (1984). Private Woman, Public Stage: Literary Domesticity in Nineteenth-Century America. New York: Oxford University Press, p. VIII.

[3] Baym (1978), p. 12.

[4] Cummins MS (1988 [1854]). The Lamplighter. Edited and with an Introduction by Nina Baym. New Brunswick/London: Rutgers University Press, p. 2.

[5] Cummins, p. 35.

[6] Cummins, p. 213.

[7] Davidson CN (1986). Revolution and the Word: The Rise of the Novel in America. New York: Oxford University Press, p. 124.

[8] Baym (1978), p. 24-25.

[9] Cott NF (1977). The Bonds of Womanhood: "Woman's Sphere" in New England, 1780 - 1835. New Haven: Yale University Press, p. 67.

[10] Cott, p. 64.

[11] Cummins, p. 4.

[12] loc. cit.

[13] Baym (1978), p. 49.

[14] Cummins, p. 28.

[15] Baym N (1988). Introduction. In: Cummins MS. The Lamplighter. New Brunswick/London: Rutgers University Press, p. XX.

[16] Cp. Cummins, chs. XXXVII ff.

[17] Cummins, p. 39.

[18] Cummins, p. 46.

[19] Cummins, p. 357.

[20] Cummins, p. 213.

[21] Saulsbury RR (1999). "Strong and Brave": The Culture of Womanhood in the Novels of Maria Susanna Cummins. West Lafayette, IN: Purdue University Press.

[22] Baym (1988), p. XIX.

[23] Douglas A (1977). The Feminization of American Culture. New York: Alfred A. Knopf, p. 12.

[24] Baym (1978), p. 17.
[25] Chopin K (1899/1994). The Awakening. Ed. Margo Culley. New York, London: W.W. Norton \& Co.

[26] Cp. von Heynitz B (1994). Literarische Kontexte von Kate Chopin's The Awakening. Tuebingen: Gunter Narr, pp. $182 \mathrm{ff}$.

[27] Baym (1978), p. 48.

[28] On reception topics cp. Baym N (1984). Novels, Readers, and Reviewers: Responses to Fiction in Antebellum America. Ithaca: Cornell University Press.

[29] Cummins, ch. XXII.

[30] Kelley M (1984). Private Woman, Public Stage: Literary Domesticity in Nineteenth-Century America. New York: Oxford University Press, p. 271.

[31] Kress D, Egloff G (2007). Bilder der 1950er bei Salinger, Roth und Updike. Gesellschaft und Zeitgeschichte in der US-Nachkriegsliteratur. Marburg: Tectum, pp. 56-68.

[32] Harris SK (1990). Nineteenth-Century American Women's Novels: Interpretive Strategies. Cambridge: Cambridge University Press, p. 135.

[33] Cp. Cummins, ch. VI.

[34] Cp. Cummins, ch. VIII.

[35] Baym (1988), p. XXI.

[36] Freud S (1933). Neue Folge der Vorlesungen zur Einfuehrung in die Psychoanalyse. Frankfurt: S. Fischer, p. 516.

[37] Baym (1988), p. XXIII.

[38] Baym (1978), p. 173.

[39] Tompkins J (1985). Sensational Designs: The Cultural Work of American Fiction, 1790 - 1860. New York: Oxford University Press, p. 148.

[40] Davidson (1986), p. 125.

[41] Frederick JT (1975). "Hawthorne's Scribbling Women". The New England Quarterly, 48, 2, pp. 231-240.

[42] Schulz D (1985). Fruehe amerikanische Erzaehlliteratur. In: Breinig H, Halfmann U (eds.). Die amerikanische Literatur bis zum Ende des 19. Jahrhunderts. Tuebingen: Francke, pp. 78-99.

[43] Chopin (1899/1994).

[44] Stanzel FK (2004). Otto Gross Redivivus - Lady Chatterley Revisited. ZAA, 52, 2, pp. 141-151.

[45] Peeler N (2010). The Woman of Ressentiment in When She Was Good. Philip Roth Studies, 6, 1, pp. 31-45.

[46] Egloff G (2014). Treating the Fiction of Forms: Metafiction in John Barth. Intl J Literature and Arts, 2, 1, pp. 1-5.

[47] Kerber LK (1986). Women of the Republic: Intellect and Ideology in Revolutionary America. New York: Norton.

[48] Baym N (1995). American Women Writers and the Work of History, 1790-1860. New Brunswick: Rutgers University Press.

[49] Baym (1978), p. 49. 